\title{
Strategi Fakultas Farmasi Universitas Mulawarman dalam Pemanfaatan Sumberdaya Alam Hayati Sebagai Sumber Bahan Farmasi Potensial
}

\author{
Laode Rijai \\ Dekan Fakultas Farmasi Universitas Mulawarman
}

\begin{abstract}
ABSTRAK
Keunggulan Fakultas Farmasi Universitas Mulawarman yang tercantum dalam visi dan misinya adalah pemanfaatan sumberdaya alam hayati sebagai produk farmasi yang menyehatkan dan menjadi sumber pendapatan masyarakat. Paradigma dasar perumusan visi tersebut tidak hanya berorientasi menghasilkan lulusan berkualitas, tetapi harus berperan langsung dalam perbaikan kesejahteraan masyarakat, sesuai dengan tugas dan fungsi Perguruan Tinggi yaitu pendidikan, penelitian, dan pengabdian masyarakat. Pola pendidikan yang diterapkan antara lain melalui materi kurikulum dan fasilitas laboratorium yang sesuai dengan visi dan misi tersebut yaitu (1) materi kurikulum berorientasi menemukan bahan baku produk farmasi, membuat produk farmasi yang efektif (manjur, aman, nyaman) dari bahan-bahan baku yang ditemukan, menjamin kualitas dan keamanan produk yang dihasilkan sebelum dan setelah edar, serta penggunaan produk farmasi yang efektif (manjur, aman, nyaman) dalam bentuk pelayanan kepada pasien (individu) dan masyarakat (2) laboratorium dikembangkan dalam tiga kelompok yaitu (a) laboratorium pendidikan kefarmasian sebagai tempat praktikum mahasiswa (b) laboratorium Riset dan Pengembangan Kefarmasiaan sebagai tempat riset untuk menemukan bahan baku produk farmasi (industrsi bahan baku), membuat produk farmasi (industri formulasi), menjamin mutu dan keamanan produk farmasi sebelum dan setelah edar serta (c) laboratorium praktek kerja kefarmasian yang berperan sebagai latihan kerja terkait pelayanan farmasi.
\end{abstract}

Berdasarkan visi dengan paradigma dasar tersebut, maka strategi pemanfaatan sumberdaya hayati sebagai bahan farmasi potensial yaitu (a) wajib memiliki laboratorium Riset dan Pengembangan Kefarmasian yang berperan menemukan bahan baku produk farmasi dan perbanyakannya yang bersumber dari bahan alami termasuk hayati dan sintetis atau hasil modifikasi molekul alami, pembuatan produk farmasi yang efektif dari bahan baku tersebut (b) memiliki lahan kebun farmasi herbal pendidikan sebagai tempat penanaman herbal yang telah ditemukan laboratorium riset (c) memiliki industri farmasi sederhana berupa industri bahan baku bahan farmasi dan industri farmasi formulasi atau pembuatan produk (c) memiliki DIPA-PNBP anggaran penelitian rutin minimal Rp. $1 \mathrm{M} /$ tahun untuk penelitian penemuan dan perbanyakan bahan baku bahan farmasi, penelitian formulasi produk farmasi yang efektif, serta penelitian penjaminan mutu dan keamanan produk farmasi. Obyek utama penelitian untuk penemuan bahan baku bahan farmasi adalah sumberdaya alam hayati karena Kalimantan Timur memiliki potensi tersebut. Dengan demikian Fakultas Farmasi UNMUL pada masa yang akan datang akan menemukan berbagai produk farmasi potensial dari bahan alami hayati yang dapat berperan sebagai sumber pendapatan masyarakat dan meningkatkan kualitas kesehatan masyarakat. 